スプレイフォーミングにより製造した Al-Si 系合金の組織と機械的性質

時實 直樹，佐野 秀男

渋江 和久, 大久保喜正

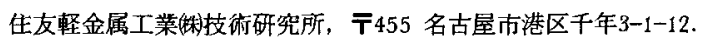

\title{
Microstructure and Mechanical Properties of Al-Si Alloy Prepared by Spray Forming
}

\author{
Naoki Tokizane, Hideo Sano \\ Kazuhisa Shibue and Yoshimasa Ohkubo
}

Technical Research Laboratories, Sumitomo Light Metal Industries, Ltd., 3-1-12 Chitose Minato-ku, Nagoya 455.

Received June 9, 1994

\begin{abstract}
Aluminium alloy materials prepared by rapidly solidification process are expanding applications with their superior properties such as lightness, strength and wear resistance. In this prospective field, spray forming (SF) is now a matter of the special interest because of its simpler process, lower cost and lower oxygen content in prochucts.

In this experiment, we prepared three SF preforms of Al-si alloy sprayed. with various "gas to metal (G/M) ratio". The microstructure and mechanical properties of the preforms and extruded materials were investigated, and found to be controled by $G / M$ ratio. The increase of $G / M$ ratio recuces primary si size and hence lowers wear resistance. On the contrary, strength of the extruded materials increases with $G / M$ ratio.
\end{abstract}

\section{1 踷言}

粉末治金法(PM法)をはじめとする急冷凝固法に よって製造されたアルミニウム合金は，その高い比 強度や耐摩耗性等により, 家電・自動車部品の分野

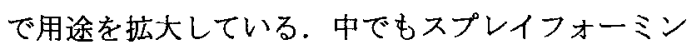
グ法(SF法)は最新プロセスのひとつとして近年特に 注目されており，当社でも英国Osprey Metals社との 技術契約に基づいて開発・実用化を進めている.

Fig.1にSF法と当社が標準的に採用しているPM法 の工程比較を示した、溶湯からプリフォーム(予備
成形体)を直接製造できるSF法が，エアアトマイ ズ・分釉・封缶・加熱真空脱ガス・ホットプレス・ 缶除去と非常に多くの工程を要するPM法に対し， 製品の短納期化, 工程数削减に伴亏品質管理の容易 さやコストダウンといった多くのメリットを有する ことがわかる1)。また アトマイズからビレット形 成までが一貫して不活性ガス雾囲気中で行われるた め，製品中に酸化物が少ない点も大きな特長である. 本稿ではVTRのヘッドシリンダに実績のあるAl-Si 系合金をSF法によって製作し，プリフォームおよび 
押出材の組織と機械的性質について調查した結果を 報告する．

SF

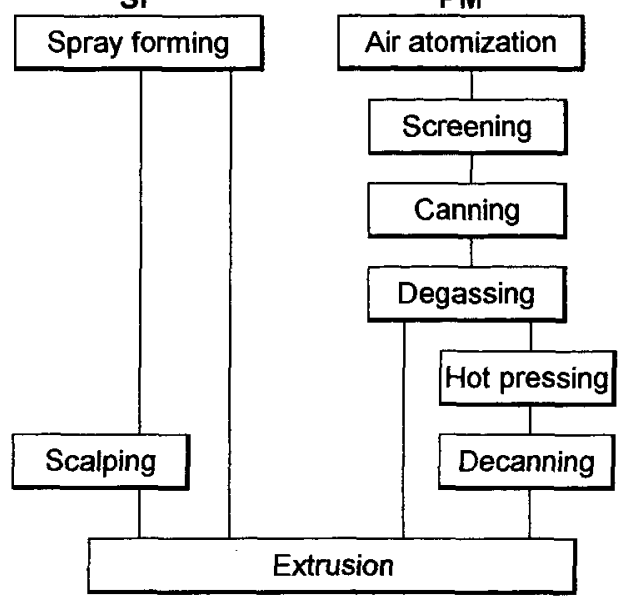

Fig. 1 Comparison between SF and PM process.

\section{2 実駼}

\section{1 装置}

Fig.2に今回の素材作製に用いたスプレイフォーミ ング設備の構成を示す．本設備は傾動式高周波誘導 溶解炉, 溶湯処理(脱ガス, 濾過および保温)装置, SF装置本体, サイクロン式集塺機からなり, 円柱状 のプリフォームを垂直に製造する，溶解能力は最大 $600 \mathrm{~kg}$ ，製作可能なプリフォーム桠質にして $380 \mathrm{~kg}$, 最大径 $500 \mathrm{~mm}$, 最大長さ $1600 \mathrm{~mm} ゙$ ある, 溶湯の脱 ガスにはアルゴン，濾過にはセラミックフォーム フィルタを使用し，アトマイズは空素ガス(液体窒 菜を気化)にて行う。なお，プリフォーム上に婎積 しなかった溶湯は，粉末(オーバースプレイパウ ダー)として集麼機にて回収される。

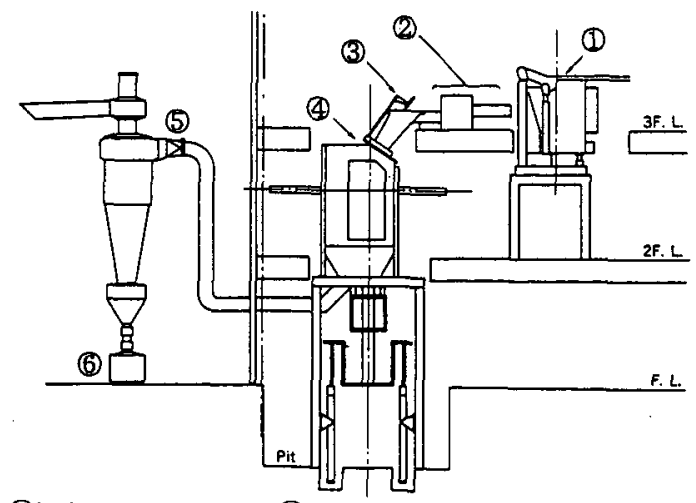

(1)Induction furnace (2)Melt-filtration unit (3)Tundish (4) $\mathrm{SF}$ unit (5) Cyclone (6) Over-spray container

Fig.2 Spray forming equipment.
2.2 プリフォームの製作

SF法による円柱状プリフォーム作製の原理は次の ようにまとめられる(Fig.3).

1) 溶湯をコレクタ(ステンレス製受け皿)の半径上 に向けてアトマイズし，コレクタを自転させる ことで面状に均一に堆積させる.アトマイズ条 件やアトマイザとコレクタの距離を適正に設定 することにより，溶湯はコレクタ上に半融半凝 固の状態で到達し，急冷凝固するとともに繳密 なプリフォームを形成する。

2) プリフォームの成長速度に合わせてコレクタを 下降させることにより堆積面は常に半融半凝固 の状態に保持され，また溶湯の堆積する面積も 一定となって，寸法変化の少なく組織の均一な プリフォームが得られる.

本研究においてはいくつかの主たるアトマイズ条 件のうち、アトマイズガス流量と溶湯流量の比であ るガスメタル比(溶湯 $1 \mathrm{~kg}$ をアマイズするのにどれ だけのガスを用いたかの指標．以下G/M比)を2.9$4.4 \mathrm{~m}^{3} / \mathrm{kg}$ の範囲で変化させ, 製品性能への影響を調 查した。ただしガス流量 $\left(\mathrm{m}^{3}\right)$ は $0^{\circ} \mathrm{C} ， 0.10 \mathrm{MPa}(1$ 気 圧)換算の值である，G/M比の調節はアトマイズガ スの圧力を変化させて行い，溶湯流量をはじめ他の スプレイ条件は全て一定とした。

今回は供試プリフォームとして 3 本を製作したが， プリフォームがある程度成長した時点で $\mathrm{G} / \mathrm{M}$ 比を変 化させる(Fig.3中の破線位置)ことで，一本のプリ フォームから複数スプレイ条件のサンプルを得た。

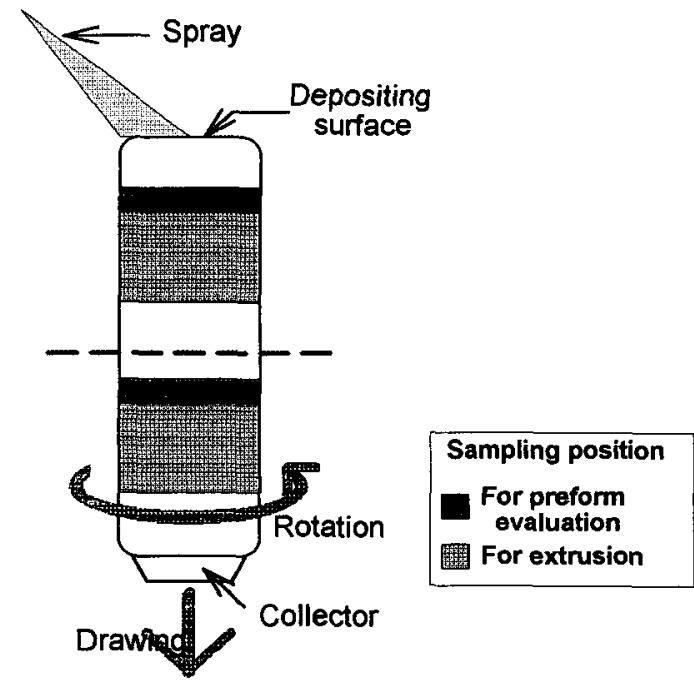

Fig.3 Schematic explanation of spray forming. 
なお押出およぴプリフォーム評価用の素材は，各 G/M比において堆積が完全に定常状態に達したと判 断される部位より採取している.

\section{3 押出および熱処理}

各G/M比によって製作したプリフォームの長手方 向より $\phi 90 \mathrm{~mm} \times 200 \mathrm{~mm}$ のビレットを切り出し, 直 接押出によって $\phi 25 \mathrm{~mm}$ (押出比14.1)とした. 押出温 度は $400^{\circ} \mathrm{C}$ ，速度は $1 \mathrm{~m} / \mathrm{min}$ (製品)である。

押出材には $495^{\circ} \mathrm{C} \times 1 \mathrm{~h}$ の溶体化処理, $175^{\circ} \mathrm{C} \times 6 \mathrm{~h}$ の 人工時効処理を施した.

\section{4 評価}

\section{4 .1 組織観察}

プリフォームおよび押出材(いずれも長手方向に 対する直角断面)より採取したサンプルを樹脂に埋 め込んで研磨し, その組織を光学顕微鏡を用いて観 察した.

\subsection{2 初晶 $\mathrm{Si}$ 粒径測定}

2.4.1の試料について, 画像解析装置を用いて初晶 $\mathrm{Si}$ 粒径(HEYWOD径＝円相当径)を測定した．観察範

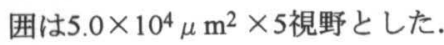

\subsection{3 引張試験}

プリフォームおよび押出材の長手方向について, インストロン型試験機による常温引張試験を行った. 試験片の平行部寸法は $\phi 8 \mathrm{~mm} \times 30 \mathrm{~mm}$, クロスヘッ ドスピードは耐力まで $1 \mathrm{~mm} / \mathrm{min}, そ の$ 後は $20 \mathrm{~mm} / \mathrm{min}$ とした.

\section{4 .4 摩耗試験}

摩耗試験に使用したpin-on-disk式摩耗試験装置の 概略をFig.4に示す.

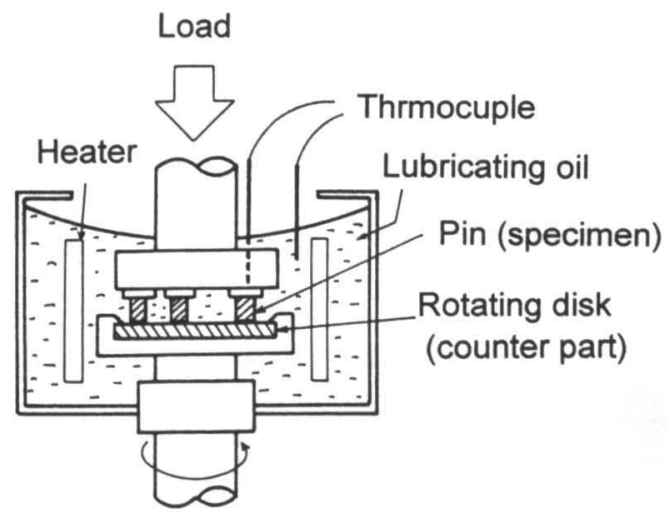

Fig.4 Schematic drawing of pin-on-disk wear testing apparatus.
試験片形状は $\phi 5 \mathrm{~mm} \times 8 \mathrm{~mm}$ であり，押出材 (T6材) の長 手方向より作製した。試験条件は荷重4.9MPa，相 手材との相対速度 $0.5 \mathrm{~m} / \mathrm{s}$ とし, 潤滑下 $\left(100^{\circ} \mathrm{C}\right.$, マシ ン油 ISOVG7)にて行った.

なお耐摩耗性は, $1 \mathrm{~h}$ 試験終了後の3本の試料の平 均摩耗量(体積)で評価した。

\section{3 結果および考察}

3.1 プリフォーム諸元

3 本のプリフォームの直径は297-316mm, 全長 1100-1450mmであった。代表的なものの外観を Photo.1に示す，外径は通常量産材であれば目標值 $\pm 5 \mathrm{~mm}$ 以内の精度で製造可能2)であるが, 本実験で はアトマイズ条件を種々に変化させたためにバラッ キが大きくなったものである.

各プリフォームの化学成分分析值はTable 1に示し た通りであり，バラツキは極めて小さかった。

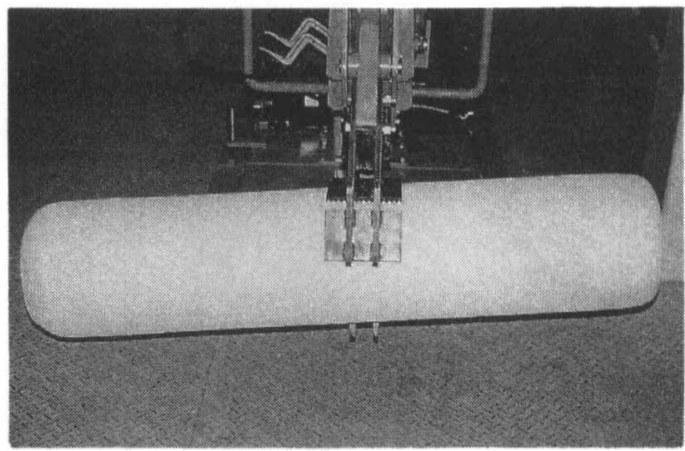

Photo.1 Appearance of preform.

Table 1 Chemical compositions

\begin{tabular}{|c|c|c|c|}
\hline No. & $\mathrm{Si}$ & $\mathrm{Cu}$ & $\mathrm{Mg}$ \\
\hline 1 & 20.0 & 1.83 & 0.77 \\
\hline 2 & 20.0 & 1.83 & 0.78 \\
\hline 3 & 20.0 & 1.80 & 0.76 \\
\hline
\end{tabular}

Photo.2にプリフォーム長手断面のマクロ組織を 示す. 表層から約 $5 \mathrm{~mm}$ の範囲には空孔が多く存在し ていたが，それ以外のプリフォーム内部にマクロ的 欠陥は認められなかった．表層のポーラスな部分は, 堆積後のプリフォーム側面に粉末が付着して生じた と考えられ，このことはPhoto. 3 に示したプリ フォーム表面のSEM組織によっても確認できる.

アルキメデス法により测定した真密度比(vs押出 材)も $99.1-99.5 \%$ (平均 $99.1 \%$ ) と高い值を示した。 


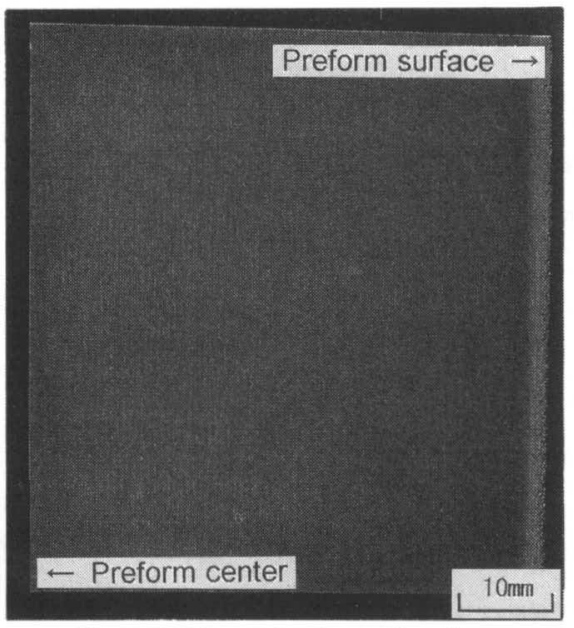

Photo. 2 Macrostructure of preform (longitudinal section).

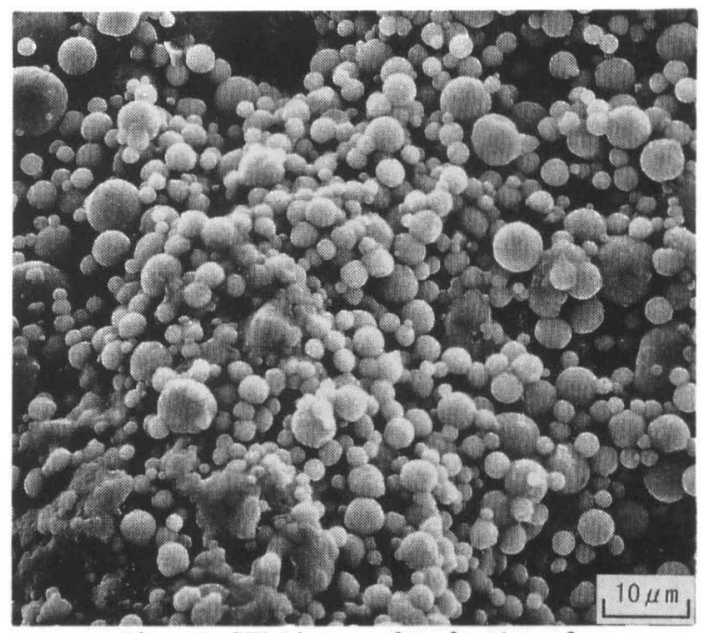

Photo.3 SEM image of preform's surface.
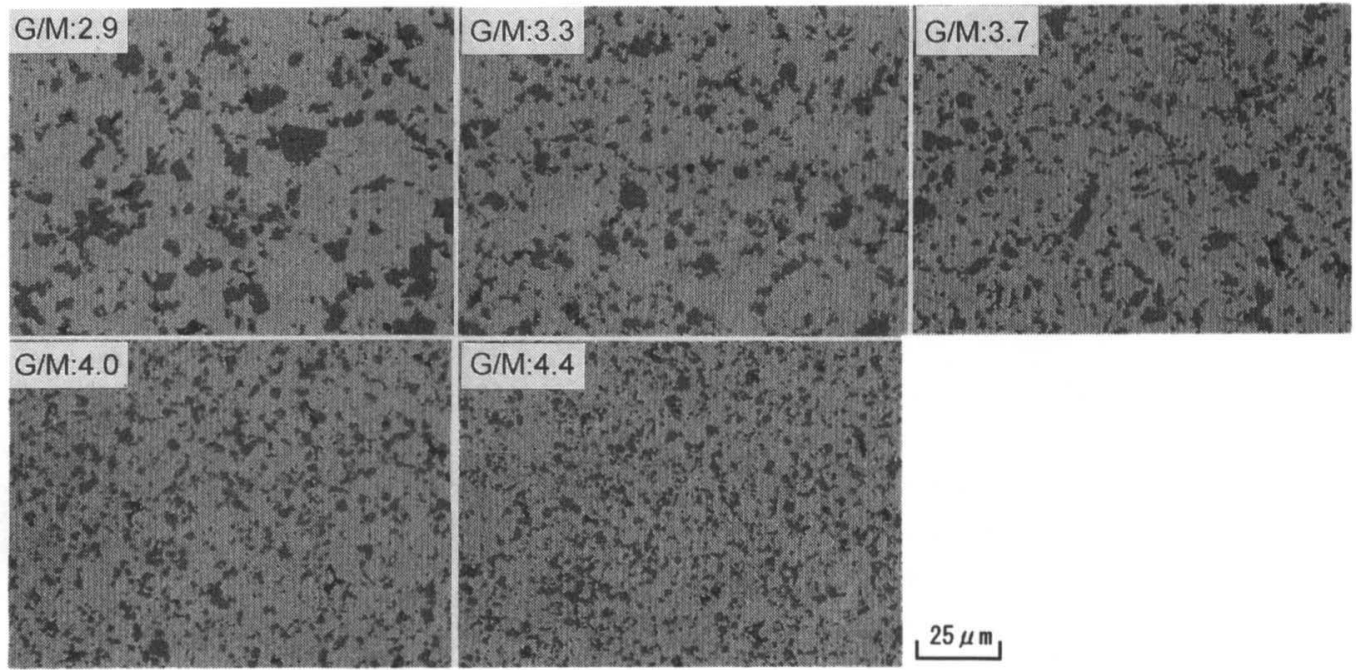

$25 \mu \mathrm{m}$

Photo.4 Microstructure of preforms.
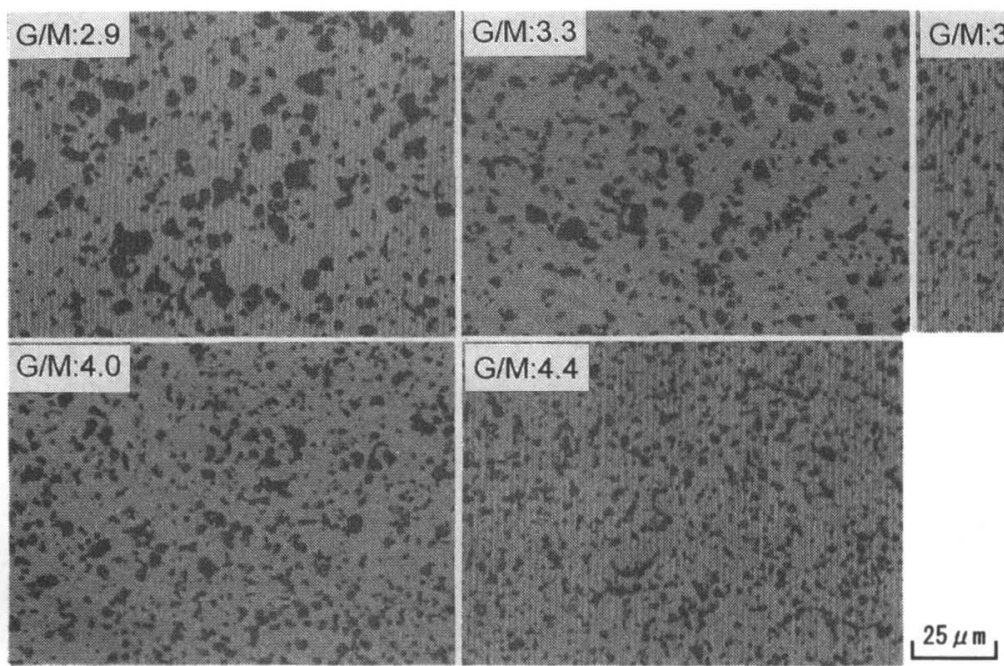

Photo.5 Microstructure of extruded materials (T6). 


\section{2 ミクロ組織}

Photo.3にプリフォームの, Photo.4に押出材(T6材) の断面ミクロ組織を示す．またFig.4に，画像解析に ようて求めたプリフォーム及び押出材(T1材，T6材) の初晶Si粒径の変化を示す.

G/M比の増大に従い，プリフォームの組織中に観 察される濃灰色の初晶Si粒子が微細になっていた. これはアトマイズで生じる液滴の径の減少, 飛行中 の液滴の泠却速度増大, 堆積後のプリフォームの汾 却速度増大という3つの相乗効果によるものと考え られる。また，押出材組織に拈いても初晶Si粒径は G/M比の増大に伴って小さくなっており，押出加工, 熱処理を経てもスプレイ時のG/M比の影響は保持さ れることが確認された。

これはすなわち，スプレイ時のG/M比を制御する ことによりプリフォーム中の，ひいては最終製品中 の初晶Si粒径を制御できることを示す.

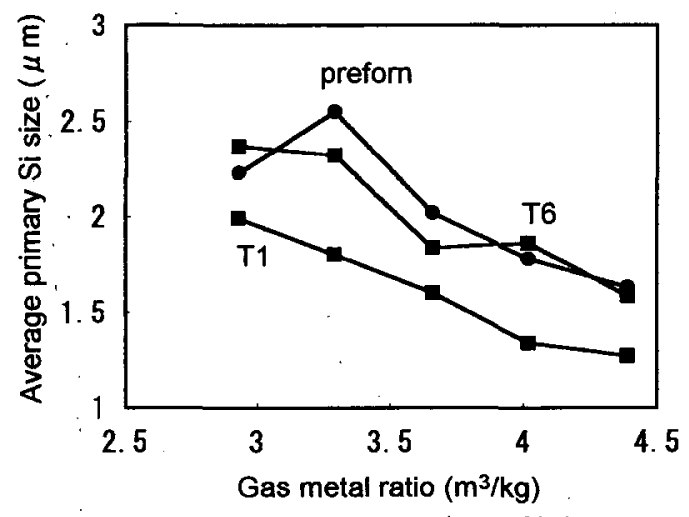

Fig.4 Relation between average primary $\mathrm{Si}$ size and $\mathrm{G} / \mathrm{M}$ ratio (preforms, $\mathrm{T} 1$ and $\mathrm{T} 6$ extrudates).

\section{3 機械的性質}

\subsection{1. 引張特性}

Fig.5に, G/M比の変化に伴うプリフォームおよび 押出材(T6材)の引張特性の変化を示す.ただし,こ こではプリフォームにも押出材同様のT6処理を施 した上で供試している.

プリフォームの耐力はほぼ一定の值を示し，引張 強さや伸びについてはG/M比が3.50付近までは上 昇するものの，その後再下降する傾向を示した。 G/M比の高い領域で引張強さや伸びが低下したのは, スプレイ時に堆積面が固相過多となって生じたポア によるものと考えられるが, 詳細については今後更 に検討の予定である。
一方押出材については伸びがほぼ一定であるのに 対し，耐力おょよび引張強さはG/M比に応じて上昇す る傾向を示した。プリフォームと特性を比較すると 伸びの増大が顥著であり，また引張強さについてむ 高G/M比側で明らかな改善が認められた。これらは， 前述したポアが押出によって消减したためであると 推定される.

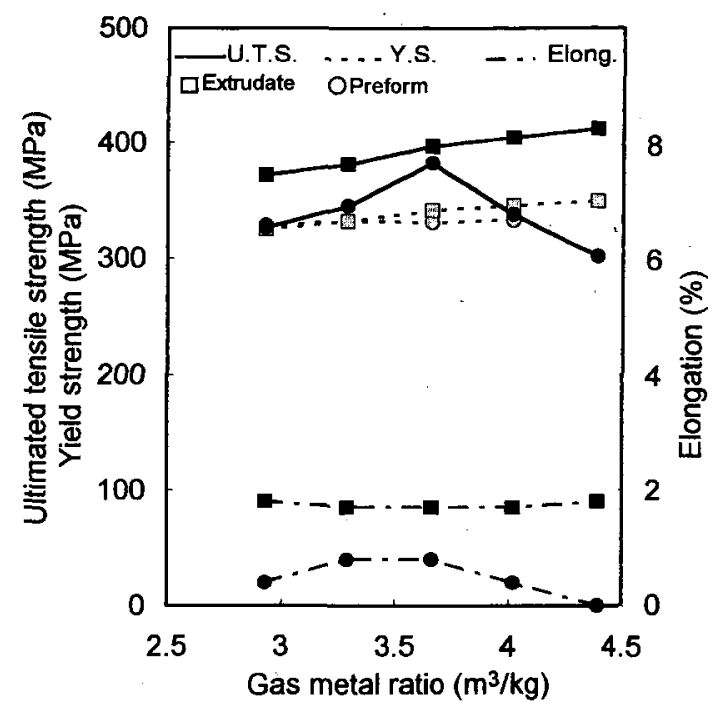

Fig. 5 Relation between mechanical properties and $\mathrm{G} / \mathrm{M}$ ratio (T6 heat treated preforms and extrudates).

\subsection{2 摩耗試験}

Fig.6に摩耗試験の結果を示す，G/M比に伴って摩 耗量が増加，すなわち耐摩耗性が低下していた。

既報3ににおて Al-Si系合金の耐摩耗性がSi粒径の 増大とともに向上することを報告しており，本実験 結果についても，G/M比の增大に伴うSi粒径の堿少 によるものと考えられた。

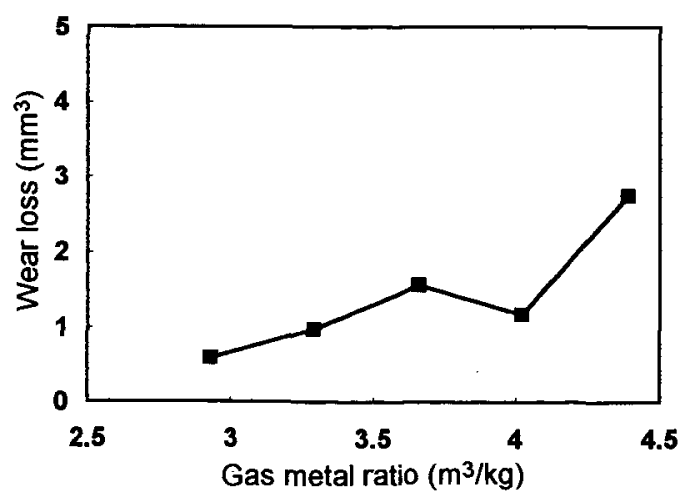

Fig. 6 Relation between wear loss and $\mathrm{G} / \mathrm{M}$ ratio (T6 extrudates). 
3.4 SF材とPM材の機械的性質の比較

SF材とPM材の性能を比較するに当たり，後者に はG/M比という概念が存在しない点がまず問題とな る.そこでSF押出材(T6材)の引張特性および面摩耗 性を, 初晶Si粒径との関係で整理した結果をFig.7に 示す. PM材通常量産品( $\mathrm{T} 6$ 押出材)の平均初晶 $\mathrm{Si}$ 粒径 は約 $2 \mu \mathrm{m}$ 程度であり，その機械的性質を図中にプ ロットすると $\Delta$ ロらになった，すなわち同等組織 のSF材とPM材を比較した場合，その機械的性質は ほぼ等しいといえる。

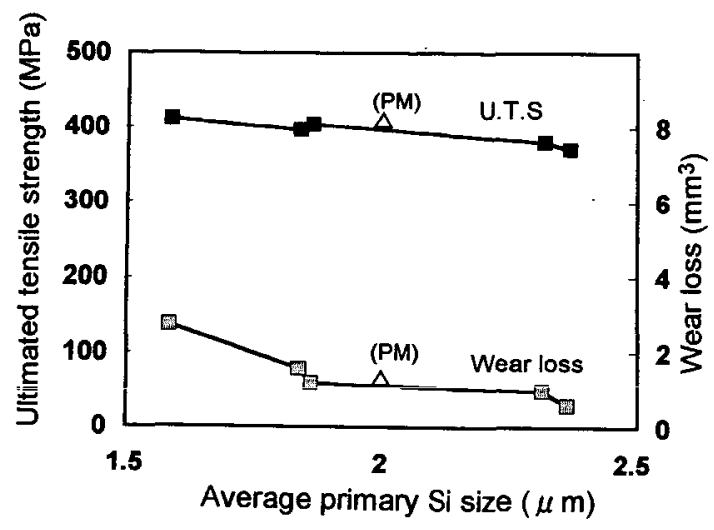

Fig.7 Relation between mechanical properties and average primary Si size (T6 extrudate of SF and PM materials).

\section{4 結論}

スプレイフォーミング法を用いてAl-Si系合金の製 作を試みるとともに，そのプリフォームおよび押出
材の組織と機械的性質について調查した結果, 以下 の結論を得た。

1) 直径約 $300 \mathrm{~mm}$, 全長 $1100-1450 \mathrm{~mm}$ のAl-20Si$\mathrm{Cu}-\mathrm{Mg}$ 合金プリフォームを作製できた.

2) プリフォーム内部にマクロ的欠宿は認められな かったが，表層部約 $5 \mathrm{~mm}$ 以内の範囲に限り多く のポロシティが存在していた.

3) スプレイ時のガスメタル比の増大に従って，プ リフォーム中の平均初晶Si粒径が減少した.こ の傾向は押出加工，熱処理を経ても保持されて おり，ガスメタル比によって最終製品の組織を 制御できることが確認された。

4) 押出加工によって引張性質の向上がみられ, 中 でも伸びの上昇が著しかった．押出材の引張強 さはガスメタル比に応じて向上し，耐摩耗性は 反対に低下した。

5) SF材を同等組織のPM材と比較した場合，その 機械的性質はほぼ等しいことが判明した。

\section{文献}

1) H.Sano, N.Tokizane, Y.Ohkubo, K.Shibue : Proceedings of Second International Conference of Spray Forming, Swansea, UK (1993), 363.

2)佐野秀男, 時實直樹, 沿江和久：轻金属学全 第85回秋期大会講演概要(1993),137.

3)大久保喜正, 浩江和久, 山内重徳：軽金属学会 第73回秋期大会講演概要(1987), 103. 